\title{
A qualitative study of the knowledge, behaviour and attitudes of patients with skin cancer regarding sunlight exposure and vitamin D
}

DOI:

10.1111/phpp.12311

\section{Document Version}

Accepted author manuscript

Link to publication record in Manchester Research Explorer

Citation for published version (APA):

Rutkowski, D., Farrar, M., Osman, J., Webb, A., \& Rhodes, L. (2017). A qualitative study of the knowledge, behaviour and attitudes of patients with skin cancer regarding sunlight exposure and vitamin D. Photodermatology Photoimmunology and Photomedicine. https://doi.org/10.1111/phpp.12311

\section{Published in:}

Photodermatology Photoimmunology and Photomedicine

\section{Citing this paper}

Please note that where the full-text provided on Manchester Research Explorer is the Author Accepted Manuscript or Proof version this may differ from the final Published version. If citing, it is advised that you check and use the publisher's definitive version.

\section{General rights}

Copyright and moral rights for the publications made accessible in the Research Explorer are retained by the authors and/or other copyright owners and it is a condition of accessing publications that users recognise and abide by the legal requirements associated with these rights.

\section{Takedown policy}

If you believe that this document breaches copyright please refer to the University of Manchester's Takedown Procedures [http://man.ac.uk/04Y6Bo] or contact uml.scholarlycommunications@manchester.ac.uk providing relevant details, so we can investigate your claim.

\section{OPEN ACCESS}


PROF. LESLEY E RHODES (Orcid ID : 0000-0002-9107-6654)

Article type : Original Article

A qualitative study of the knowledge, behaviour and attitudes of patients with skin cancer regarding sunlight exposure and vitamin D

D. Rutkowski ${ }^{1}$, M.D. Farrar ${ }^{1}$, J.E. Osman ${ }^{1}$, A.R. Webb ${ }^{2}$, L.E. Rhodes ${ }^{1}$

${ }^{1}$ Division of Musculoskeletal and Dermatological Sciences, Faculty of Biology Medicine and Health, University of Manchester, Manchester Academic Health Science Centre, Salford Royal Hospital, Manchester, UK

${ }^{2}$ School of Earth and Environmental Sciences, Faculty of Science and Engineering, University of Manchester, Manchester, UK

Running head: Vitamin D awareness in skin cancer patients

Key Words: Vitamin D, Skin cancer, Sun exposure recommendations, Health Belief Model

Funding sources: This study was funded by the U.K. Department of Health Policy Research

Programme 024/0050.

Conflict of interests: None.

This article has been accepted for publication and undergone full peer review but has not been through the copyediting, typesetting, pagination and proofreading process, which may lead to differences between this version and the Version of Record. Please cite this article as doi: 10.1111/phpp.12311

This article is protected by copyright. All rights reserved. 
Corresponding author:

Professor L. E. Rhodes, Photobiology Unit, Dermatology Centre, University of Manchester, Salford Royal Hospital, Stott Lane, Salford, Greater Manchester, M6 8HD.

Email: lesley.e.rhodes@manchester.ac.uk; Tel: +44 1612061150

\begin{abstract}
Background Solar UVR is a major cause of skin cancer but also an important source of vitamin D (VitD), essential for musculoskeletal health. Conflicting public health messages may confuse skin cancer patients prone to further skin cancer.

Objective To explore the knowledge, behaviour and attitudes of skin cancer patients to sunlight exposure and VitD sources.

Methods Patients ( $n=10$ ) previously treated for multiple basal cell cancer in a hospital setting, participated in focus group sessions with semi-structured discussions to explore: knowledge of VitD, sun-avoidance behaviour, and attitude towards sunlight exposure messages. Thematic data analysis was performed using software programme MAXQDA11.

Results Pre-existing knowledge of VitD was low. Most patients practiced sun-avoidance and were not inclined to increase exposure. Patients did not perceive VitD deficiency as a substantial risk to their own health, or a need to take VitD supplements. They aimed to increase VitD status through dietary intake, but knowledge of food VitD content was lacking. Conclusions The skin cancer patients, appropriate to their heightened skin cancer risk, appeared unlikely to increase their sun-exposure to gain VitD. However, education is required regarding the generally low levels of VitD in foodstuffs, and the requirement for supplements/fortified foods if strict sun-avoidance is employed.
\end{abstract}

This article is protected by copyright. All rights reserved. 


\section{Introduction}

Low vitamin D (VitD) levels are prevalent in the United Kingdom (UK) as well as in other northerly climes, particularly during the winter months, with high proportions of the general population regarded as VitD insufficient according to European and USA/Canadian authorities i.e. with serum 25-hydroxyvitamin D (25(OH)D) less than $50 \mathrm{nmol} / \mathrm{L}(20 \mathrm{ng} / \mathrm{ml})$ and substantial numbers deficient, with 25(OH)D levels less than $25 \mathrm{nmol} / \mathrm{L}(10 \mathrm{ng} / \mathrm{ml})(1-8)$. However, VitD is essential for musculoskeletal health.

VitD is predominantly obtained through cutaneous synthesis. Conversion of 7dehydrocholesterol to pre-vitamin $D_{3}$ by ultraviolet $B$ (UVB) radiation in sunlight is followed by heat-isomerisation to vitamin $D_{3}$ (cholecalciferol) which is released into the circulation. This is metabolized in the liver to $25(\mathrm{OH}) \mathrm{D}$ (calcidiol) and subsequently in the kidney to the active metabolite 1,25 -dihydroxyvitamin $\mathrm{D}\left(1,25(\mathrm{OH})_{2} \mathrm{D}\right.$; calcitriol), which mediates its actions through the VitD receptor (9). VitD promotes absorption of dietary calcium and bone mineralization, with deficient levels resulting in rickets and osteomalacia. Low VitD status is also linked to secondary hyperparathyroidism, osteoporosis and increased risk of fractures (9). A number of autoimmune and systemic disorders including multiple sclerosis, diabetes and cardiovascular disease, and a range of malignancies, show associations with low VitD, although causality is not proven $(4,10,11)$.

Sun-exposure recommendations emphasize minimization of sunlight exposure in an attempt to stem the rising incidence of skin cancers, for which solar ultraviolet radiation (UVR) is the major exogenous cause. Recently, public health recommendations also allow for brief exposures to sunlight as these may achieve adequate VitD status $(12,13,14)$. Recently, the UK's Scientific Advisory Committee on Nutrition (SACN) has recommended

This article is protected by copyright. All rights reserved. 
that everyone from 1 year of age upwards takes $10 \mu \mathrm{g}$ oral VitD daily during the winter months, and that this should apply year-round in those who have low exposure to sunlight (4).

Skin cancer prevalence in the UK, as in many countries with light-skin populations, is increasing and has become a significant cause of morbidity and mortality (1). Through campaigns and government policies the general population has become increasingly aware of the link between sunlight and skin cancer, and the role of sun protective measures. However, the benefits of adequate VitD status may be less generally appreciated (15). In addition, patients who have previously suffered from skin cancer are actively encouraged to avoid direct sunlight and to rigorously use sun protective measures which may impact on their VitD levels, although compliance with this advice may be variable $(16,17)$.

Patients with a history of skin cancer are at heightened risk of further skin cancer, and messages regarding both the health risk and benefit of sunlight may cause confusion $(18,19)$. Therefore we conducted focus groups with patients who have previously suffered from skin cancer in order to appraise (i) their knowledge of VitD health benefits and acquisition, (ii) their own sun protection/exposure behaviour (iii) their attitude towards messages on summer sunlight exposure, including advice regarding brief exposures to assist VitD production.

\section{Patients and Methods}

This was a qualitative study employing standard methodology (20-22) for focus group research. It explored patients' knowledge of VitD, their current sunlight protection/exposure behaviour, and their attitude towards sun-exposure recommendations. Ethical approval was obtained from the Greater Manchester West NHS Research Ethics

This article is protected by copyright. All rights reserved. 
Committee (ref. 14/NW/1100). Written informed consent was obtained from all patients and the study complied with the principles of the Declaration of Helsinki.

Patients who had been previously treated for more than two basal cell carcinomas (BCC) were recruited from the Dermatology Centre, Salford Royal NHS Foundation Trust, UK. Inclusion criteria were patients aged eighteen years or over, with a previous confirmed diagnosis of BCC. Patients with co-existing dermatological conditions were excluded. Participants $(n=10)$ were recruited into two focus groups of $n=5$. A facilitator gave a brief introduction to the study then explored the patients' initial knowledge of VitD health effects, its acquisition, and their current sun-exposure and photoprotective behaviour. A topic guide was used to assist focus group discussions; this comprised a number of openended questions beginning with general questions about sunlight and VitD and leading to more specific queries about sun exposure. Following this, the facilitator provided and verbally presented information which explained the health benefits and sources of VitD acquisition. This included messages regarding brief sunlight exposures, specifically 15 minutes of summer sun-exposure around lunchtime on most days of the week, for gaining VitD. A further series of open-ended questions was then asked to encourage discussion regarding their attitudes towards these recommendations. Discussion was encouraged to continue until no new information was forthcoming. Group discussions lasted between 45 and 60 minutes and were digitally recorded.

Audio recordings were transcribed into Microsoft Word and imported to MAXQDA11 (VERBI, Berlin-professional qualitative data analysis software) for coding and analysis. Comments from the interviews were analysed using systematic text condensation (23) and broadly classified into the themes conforming to (i) knowledge, (ii) attitudes and (iii) behaviour in relation to the national guidance.

This article is protected by copyright. All rights reserved. 


\section{Results}

10 patients, median age 78.5 years (range 40-84 years; 6 male; all white Caucasian), previously treated for multiple basal cell carcinomas were recruited into this study, their demographics are presented in Table 1. One patient had Gorlin's syndrome. Subjects' comments are coded according to subject (S) 1-10.

\section{1) Vitamin D Knowledge:}

All participants had heard of VitD, but none could recall being given specific written or verbal information in any context:

\section{Q: Where did you learn about vitamin D?}

S4: "I find it quite amazing that I've been having this treatment for 3 years, and the first time that someone at the hospital has mentioned vitamin D, this is the first time".

S1: “Vitamin D hasn't been mentioned any time during my treatment. Plenty of mention of sunlight, but not of vitamin D".

This translated into a widely variable understanding of VitD with the majority of patients exhibiting very little understanding compared to a minority who associated VitD with calcium:

\section{Q: What do you know about vitamin $D$ ?}

S1: "Don't know a thing"

S4. "I know you need vitamin D in order for your body to absorb calcium, that's probably the extent of my knowledge"

This article is protected by copyright. All rights reserved. 
Nearly all patients were aware that the primary source of VitD was the sun, however a paucity of knowledge existed regarding minimum skin exposure and duration required to achieve adequate levels. A minority of patients stated they were aware that it was found in a number of foods:

\section{Q: What sources of vitamin D are you aware of?}

S1/2/3/4/5: "Sun"

S3: "Green vegetables"

S2: "Fruit"

S5: "Fish oils and liver"

S6: “Eggs?"

S8: "Very little"

Q: How much skin do you think you would need to expose to get enough vitamin D?

S1: "No idea. I know how much skin I do expose, but I have no idea how much I would need to get enough vitamin D. This is all new"

S2: "Arms and face, that's about it really"

Patients were aware of some potential consequences of inadequate VitD status compared to the benefits of adequacy. In particular, rickets was a common perceived threat for children, which may reflect the older age group of our patients; however very few had concerns for their own current health:

\section{Q: Do you think that vitamin D is important for our health?}

S1/2/6/7: "It's associated with rickets."

S3: "Something to do with blood cells isn't it, white blood cells probably."

S5: "Is rickets making a comeback because children aren't going outside, playing?"

This article is protected by copyright. All rights reserved. 


\section{Q: $\quad$ Have you ever been concerned about your vitamin D levels?}

S4/5/6: "No, never."

S2: "Not really, no."

\section{2) Behaviour:}

For most patients, having had skin cancer had profoundly impacted on their current sun exposure behaviour. In these patients, their perceived risk of sunlight exposure had persuaded them to adopt tactics to avoid direct exposure or use sun protective measures:

\section{Q: How do you try to avoid the sun?}

S2: 'Well I don't go outside during those hours [11am-3pm], specifically because I've had so many problems."

S10: "More often than not I sit in the shade anyway and just have limited time out"

\section{Q: Do you wear sunscreen regularly?}

S3: "All the time - now I do. I didn't use to"

S10: "Yes, sunscreen and a hat".

While most patients actively avoided direct sunlight or used appropriate protection, there were two individuals for whom their past experience appeared to have had little or no impact, and consequently they exposed themselves to greater amount of sunlight than advised:

This article is protected by copyright. All rights reserved. 


\section{Q: How do you try to avoid the sun? \\ S8: "I'm out most of the time. Golf, cricket, gardening". \\ Q: Do you wear sunscreen regularly? \\ S1: "I haven't done for the last 6 years or so".}

Within those using sun protective measures, there were insights into the consequences this could have on their VitD status:

Q: Do you think wearing sunscreen and avoiding the sun affects vitamin D?

S1: "No idea".

S2: "You can still get a sun tan, so I imagine that enough does get through"

S3: "Well yes obviously, if you're keeping the rays out".

\section{3) Patients' attitudes towards sunlight recommendations to gain vitamin D}

Most patients had concerns, personally, following recommendations for brief sunlight exposures. Their previous experience of skin cancer had affirmed that they should actively avoid sunlight, reinforced by advice from clinicians. Conversely a minority of patients felt that 15 minutes of sunlight exposure represented a minimal risk, which they already took.

\section{Discussion}

Skin cancer campaigns have previously delivered a clear and concise message of sun avoidance to reduce the risk of skin cancer. With enhanced awareness of low VitD levels at population level, and the role of VitD in musculoskeletal health, there are now public messages allowing for brief exposures to summer sunlight. On the other hand, increased oral ingestion is advised, particularly for 'at risk groups' who receive little VitD from sun-

This article is protected by copyright. All rights reserved. 
exposure (4). Conflicting messages on sun exposure to avoid harm and gain benefit could cause confusion for patients already at increased risk of harm from sunlight. Therefore we have explored through focus groups, the knowledge, behaviour and attitudes towards VitD and sun-exposure guidance in patients with a history of treatment for multiple skin cancers. The focus group is a commonly-used approach that can effectively explore individuals' views and beliefs about key topics, to understand factors influencing attitudes and behaviours (20); this methodology provides insights that would not be accessible via other research methods $(21,22)$. Group sizes of 4 to 8 people are suggested to be optimal $(21)$.

Although all the skin cancer patients were aware of VitD, there was, in general, a considerable lack of knowledge. Indeed, a number of patients exhibited frustration at the lack of information available and welcomed further education. Most patients recognised that complications can arise from VitD deficiency, particularly in childhood, but very few were able to identify the benefits of achieving sufficient levels. Despite associating VitD deficiency with health risks, none within the group had been concerned about their own status or had requested VitD blood tests, which may represent a lack of knowledge in attaining such investigations, or be attributable to the minimal risk that patients perceived low VitD levels to be to their own health.

Most patients associated VitD deficiency with rickets, a severe bone deficiency disorder which although uncommon does still persist in the UK with an incidence of 7.5 in 100,000 children under the age of 5 (24). The disparity in our patients' age and their concern for a childhood disease is likely to be a reflection of the media interest in rickets, and possibly their recollection of health campaigns specifically targeting this condition in the 1950 's-60's (25). Although one patient identified VitD with calcium absorption there was a

This article is protected by copyright. All rights reserved. 
lack of awareness of the benefit that satisfactory levels could have on their own musculoskeletal health; this may be an area for future health campaigns to focus upon (26).

The health belief model (HBM) was developed in the 1950's to address and understand the failure of people to adopt preventative measures in asymptomatic disease (27). Simplistically, the HBM states that behaviour depends on the patients' perception of a number of variables including: susceptibility, severity, benefits, barriers and cue to action. This study indicated that experience of skin cancer profoundly influenced the patients' attitudes and behaviour towards sun exposure. Their perceived risk of developing skin cancer was greater than their perceived risk of VitD deficiency, and prudently they employed a number of UVR protective measures. When asked for their views on recommendations for brief ( 15 minutes) of sunlight exposure, most patients exhibited awareness of the potential harm this could cause their skin in view of their susceptibility to skin cancer, and would be hesitant to follow these, although a minority mentioned that they already spend in excess of this time.

Health campaigns aiming to prevent skin cancer have focused on minimizing sun exposure and promoting sunscreen use (12). In extreme sunlight risk groups, e.g. immunosuppressed organ transplant recipients, total sunlight avoidance in peak UVR hours is recommended, and use of a sunscreen product of at least SPF 15 on exposed skin (28). Although there is debate as to what degree sunscreen use reduces VitD synthesis in the public in practice, considering it is generally applied suboptimally (more thinly and less evenly than under manufacturer's test conditions), it has been reported that in patients with skin cancer, the use of sunscreen on a daily basis can reduce VitD levels to half of those in healthy individuals who do not use sunscreen $(29,30)$. In our skin cancer patients, the

This article is protected by copyright. All rights reserved. 
majority replied that they regularly applied sunscreen or employed UVR protective measures, and they therefore can be regarded as an at risk group for lower VitD levels.

Despite being informed of the risk of low VitD status, patients were generally not keen to increase their intake in the form of supplements. The older age group of the patients, with predisposition to chronic diseases requiring daily medications, led to some reluctance to increase their polypharmacy. Patients wished to increase their VitD intake 'naturally' through diet. Unfortunately, the majority of natural foods, other than oily fish, contain only low amounts of VitD, while the patients had little knowledge of food VitD content, or that food in general does not provide an adequate source. While the number of patients involved ( $n=10)$ is appropriate for focus group study (21), the overall number studied is not large, all had 2 or more BCC, and all but one were 65 years or older; thus findings may not be generalizable to a wider population.

Avoiding VitD deficiency in skin cancer patients is a complex public health issue, requiring policy makers to address a number of specific challenges. This study highlights the benefits of exploring patients knowledge, behaviour and attitudes, rather than simply adopting a paternalistic approach, for example when advising oral VitD supplements, which the patients were discovered to be hesitant to adopt. This hesitancy could potentially be addressed by patient education into both the benefits of VitD and the risks of low levels to health. Enhanced food fortification with VitD could be an alternative approach.

\section{Acknowledgements}

This was independent research commissioned and funded by the Department of Health Policy Research Programme (Ref. 024/0050). Views expressed are the authors, not necessarily those of the Department of Health.

This article is protected by copyright. All rights reserved. 


\section{References}

1. de Vries E, Bray FI, Coebergh JW, Parkin DM. Changing epidemiology of malignant cutaneous melanoma in Europe 1953-1997: rising trends in incidence and mortality but recent stabilizations in western Europe and decreases in Scandinavia. Int J Cancer 2003; 107: 119-126.

2. Department of Health. Dietary reference values for food energy and nutrients for the United Kingdom. Report on Health and Social Subjects 41. 1991. London: Stationery Office. 3. Department of Health. Nutrition and bone health with particular reference to calcium and vitamin D. Report on Health and Social Subjects 49. 1998. London: Stationery Office.

4. Scientific Advisory Committee on Nutrition. Vitamin D and Health. 2016. Available at: https://www.gov.uk/government/publications/sacn-vitamin-d-and-health-report (accessed 7 September 2016)

5. Hyppönen E, Power C. Hypovitaminosis D in British adults at age 45 y: nationwide cohort study of dietary and lifestyle predictors. Am J Clin Nutr 2007; 85: 860-868.

6. Pearce SH, Cheetham TD. Diagnosis and management of vitamin D deficiency. BMJ 2010; 340: b5664.

7. Institute of Medicine. Dietary reference intakes for calcium and vitamin D. 2011. Washington, DC: The National Academy Press.

8. European Food Safety Authority Panel on Dietetic Products Nutrition and Allergies. Scientific opinion on dietary reference values for vitamin D. EFSA J 2016; 14: in press. 9. Holick MF. Vitamin D deficiency. N Engl J Med 2007; 357: 266-281.

10. Zittermann A. Vitamin D in preventive medicine: are we ignoring the evidence? Br J Nutr 2003; 89: 552-572.

This article is protected by copyright. All rights reserved. 
11. Holick MF. Vitamin D status: measurement, interpretation, and clinical application. Ann Epidemiol 2009; 19: 73-78.

12. Cancer Research UK. Sun, UV and cancer. Available at: http://www.cancerresearchuk.org/about-cancer/causes-of-cancer/sun-uv-andcancer/ways-to-enjoy-the-sun-safely (accessed 7 September 2016)

13. National Radiation Protection Board. Health Effects of Ultraviolet Radiation. NRPB, 2002. 14. Rhodes LE, Webb AR, Fraser HI, Kift R, Durkin MT, Allan D, O’Brien SJ, Vail A, Berry JL. Recommended Summer Sunlight Exposure Levels Can Produce Sufficient ( $\geq 20 \mathrm{ng} \mathrm{ml} / \mathrm{L}$ ) but Not the Proposed Optimal ( $\geq 32 \mathrm{ng} \mathrm{ml} / \mathrm{L}$ ) 25(OH)D Levels at UK Latitudes. J Invest Dermtol 2010; 130: 1411-18.

15. Vu LH, van der Pols JC, Whiteman DC, Kimlin MG, Neale RE. Knowledge and attitudes about Vitamin D and impact on sun protection practices among urban office workers in Brisbane, Australia. Cancer Epidemiol Biomarkers Prev 2010; 19: 1784-1789.

16. Skiveren J, Mortensen EL, Haedersdal M. Sun protective behaviour in renal transplant recipients. A qualitative study based on individual interviews and the Health Belief Model. J Dermatolog Treat 2010; 21: 331-336.

17. Gillie O. A new government policy is needed for sunlight and vitamin D. Br J Dermatol 2006; 154: 1052-1061.

18. Lear JT, Tan BB, Smith AG et al. Risk factors for basal cell carcinoma in the UK: casecontrol study in 806 patients. J R Soc Med 1997; 90: 371-374.

19. National Institute for Health and Care Excellence. Communicating Sunlight Health Risks and Benefits. February 2016. https://www.nice.org.uk/guidance/ng34 (accessed 7 September 2016)

20. Hennink M, Diamond I. Using Focus Groups in Social Research. In: Memon A and Bull R, This article is protected by copyright. All rights reserved. 
eds. Handbook of the Psychology of Interviewing. 1999: 113-141.

21. Albrecht TL, Johnson GM, Walther JB. Understanding communication processes in focus groups. In: Successful Focus Groups: Advancing the State of the Art. Morgan DL, ed. Newbury Park: Sage Publications, 1993: 51-64.

22. Kitzinger J. Qualitative research. Introducing focus groups. BMJ 1995; 311:299-302.

23. Malterud K. Systematic text condensation: a strategy for qualitative analysis. Scand J Public Health 2012; 40: 795-805.

24. Callaghan AL, Moy RJ, Booth IW, Debelle G, Shaw NJ. Incidence of symptomatic vitamin D deficiency. Arch Dis Child 2006; 91: 606-607.

25. Bivins R. Ideology and disease identity: the politics of rickets, 1929-1982. Med Humanit 2014; 40: 3-10.

26. Sunyecz JA. The use of calcium and vitamin D in the management of osteoporosis. Ther Clin Risk Manag 2008; 4: 827-836.

27. Janz NK, Becker MH. The Health Belief Model: a decade later. Health Educ Q 1984; 11: 147.

28. Rose RF, Moniem K, Seukeran DC, Stables GI, Newstead CG. Compliance of renal transplant recipients with advice about sun protection measures: completing the audit cycle. Transplant Proc 2005; 37: 4320-4322.

29. Norval M, Wulf HC. Does chronic sunscreen use reduce vitamin D production to insufficient levels? Br J Dermatol 2009; 161: 732-736.

30. Matsuoka LY, Wortsman J, Hanifan N, Holick MF. Chronic sunscreen use decreases circulating concentrations of 25-hydroxyvitamin D. A preliminary study. Arch Dermatol 1988;

124: $1802-1804$.

This article is protected by copyright. All rights reserved. 
Table 1. Demographics of the skin cancer (all BCC) patients

\begin{tabular}{|c|c|c|c|c|}
\hline Patient & Age & Sex & BCC type; No. lesions; Anatomical location & Previous treatments \\
\hline 1 & 80 & $\mathrm{~F}$ & Nodular; 2; right ankle & PDT, surgery \\
\hline 2 & 80 & M & Superficial; multiple; face, upper trunk, lower limbs & $\begin{array}{l}\text { 2x PDT, surgery, } \\
\text { Imiquimod }\end{array}$ \\
\hline 3 & 84 & M & $\begin{array}{l}\text { Superficial; 4; lower limbs } \\
\text { Nodular infiltrative; } 1 \text {; left shin }\end{array}$ & Surgery, PDT \\
\hline 4 & 81 & $\mathrm{~F}$ & $\begin{array}{l}\text { Superficial; 2; scalp, forehead } \\
\text { Morphoeic; } 1 \text {; left parietal region }\end{array}$ & PDT, Mohs \\
\hline 5 & 78 & M & $\begin{array}{l}\text { Superficial; } 1 \text {; upper back } \\
\text { Nodular; } 1 \text {; forehead }\end{array}$ & PDT, Mohs \\
\hline 6 & 68 & M & $\begin{array}{l}\text { Superficial; 3; right scapula } \\
\text { Infiltrative morphoeic; } 2 \text {; left upper neck } \\
\text { Nodular; } 1 \text {; right forearm }\end{array}$ & $\begin{array}{l}\text { PDT, Curette and } \\
\text { cautery, Mohs }\end{array}$ \\
\hline 7 & 79 & M & Nodular; 2; upper back & PDT, surgery \\
\hline 8 & 73 & M & $\begin{array}{l}\text { Superficial; } 2 \text {; mid and right back } \\
\text { Nodular; } 1 \text {; tip of nose }\end{array}$ & PDT, Mohs \\
\hline 9 & 40 & $\mathrm{~F}$ & $\begin{array}{l}\text { Superficial; 2; right arm } \\
\text { Infiltrative; } 1 \text {; upper lip } \\
\text { (Gorlin syndrome) }\end{array}$ & PDT, surgery \\
\hline 10 & 65 & $\mathrm{~F}$ & Superficial; 2; left upper back, right upper arm & PDT \\
\hline
\end{tabular}

This article is protected by copyright. All rights reserved. 